\title{
СУАОВА МЕАИЦИНА
}

https://doi.org/10.35339/msz.2019.83.02.13

УДК 340.66:[616.22+616.716.5]-001.3-091

\section{М.В. Губін}

Харківський національний медччний університет

\section{СУДОВО-МЕДИЧНА ОЦІНКА ТЯЖКОСТІ ПОСТТРАВМАТИЧНИХ ЗМІН ПІД'ЯЗИКОВО-ГОРТАННОГО КОМПЛЕКСУ У СМЕРТЕЛЬНИХ ВИПАДКАХ}

\begin{abstract}
Установлено особливості проведення судово-медичних експертиз при визначенні ступеня тяжкості тілесних ушкоджень за смерті постраждалих осіб із травмами під’язиковогортанного комплексу. Проаналізовано методичне забезпечення для адекватного судовомедичного оцінювання таких травм. За аналізу чітких діагностичних критеріїв, які дозволяють об' єктивно визначати ступінь тяжкості тілесних ушкоджень при смерті осіб із травмами під’язиково-гортанного комплексу, не виявлено. Визначено шляхи подальшого вдосконалення судово-медичного оцінювання вказаних ушкоджень у випадках смерті постраждалих.

Ключові слова: судово-медична експертиза, травма під'язиково-гортанного комплексу, діагностичні критерії, ступінь тяжкості тілесних ушкоджень.
\end{abstract}

\section{Вступ}

Під’язиково-гортанний комплекс (ПГК) $є$ важливим анатомічним утворенням людини, ушкодження структур якого нерідко призводить до розвитку небезпечних для життя явищ і смерті [1]. Разом із тим постраждалі з травмою ПГК нерідко стають об'єктом судовомедичної експертизи. Під час судово-медичних експертних досліджень правоохоронними органами перед фахівцями ставиться коло питань, зокрема встановлення причини смерті, характеру, механізму травми та засобу їі заподіяння $[2,3]$. Одним із головних питань $€$ визначення ступеня тяжкості тілесних ушкоджень, заподіяних померлому [4].

Відповідно до п. 4.8 «Правил судово-медичного визначення ступеня тяжкості тілесних ушкоджень» (Наказ МО3 України від 17.01.95 № 6)» [5], якщо в постанові про призначення експертизи міститься питання про ступінь тяжкості тілесних ушкоджень у випадку смерті постраждалої особи, судово-медичний експерт зобов'язаний зазначити, чи мають ці ушкодження ознаки тяжкого, середньої тяжкості чи легкого ушкодження, посилаючись на відповідні пункти «Правил...». Саме це є критерієм для визначення судом міри кримінального покарання кожної особи, яка заподіяла тілесні ушкодження постраждалому.

Під час судово-медичної експертизи у випадках смерті постраждалих із травмами ПГК наявні посттравматичні зміни у вигляді повного порушення цілості стінки гортані, а також переломи під'язикової кістки за наявності загрозливих життю явищ згідно 3 п. 2.1.3 i, ї «Правил...» [5] однозначно оцінюють як тяжкі, небезпечні для життя тілесні ушкодження. У зв' язку з цим судово-медичне оцінювання випадків таких травм ПГК є нескладним для судово-медичних експертів. Разом із тим при травмах ПГК, що супроводжуються переломами хрящів гортані, ізольованими перелома-

(C) М.В. Губін, 2019 
ми під'язикової кістки, може не відбуватись повного порушення цілості стінки гортані та виникнення небезпечних для життя явищ [6]. $\mathrm{У}$ цих випадках судово-медичне визначення ступеня тяжкості травм ПГК повинно здійснюватись за кінцевими результатами травми.

Крім того, при судово-медичному визначенні у померлих осіб ступеня тяжкості травм ПГК, які не $\epsilon$ небезпечними для життя, у експерта немає даних щодо кінцевих результатів травми і «тривалості розладу здоров'я». У цьому випадку при визначенні ознак тілесних ушкоджень судово-медичний експерт повинен спрогнозувати можливий кінцевий результат посттравматичних змін ПГК, спираючись на відповідне науково-методичне забезпечення. За відсутності таких методичних матеріалів можливі певні труднощі при експертному оцінюванні таких випадків.

Мета даної роботи полягає у проведенні морфологічного аналізу та наданні експертної оцінки тілесним ушкодженням при закритій тупій травмі під'язиково-гортанного комплексу в померлих осіб для визначення шляхів підвищення ефективності судово-медичної діагностики зазначеної травми.

\section{Матеріал і методи}

Матеріалом для аналізу були висновки судово-медичної експертизи за матеріалами справ за фактом смерті постраждалих, у яких були наявні закриті травми ПГК. Судово-медичні експертизи було проведено на базі відділу комісійних судово-медичних експертиз Харківського обласного бюро судово-медичної експертизи протягом 2011-2018 років. Крім того, аналізували архівні висновки експертів відділу комісійних судово-медичних експертиз Харківського обласного бюро судово-медичної експертизи за вказаний період часу. Усього ретроспективно було опрацьовано 18 висновків судово-медичної експертизи.

У ході дослідження використовували такі методи:

- реєстраційний - отримані дані заносили у спеціально розроблені реєстраційні картки, які містили перелік відповідних морфологічних ознак отриманих постраждалими травм;

- стандартний метод описової статистики;

- судово-медичний - визначали характер ушкоджень, аналізували встановлені експертами ступінь тяжкості тілесних ушкоджень та причину смерті.

\section{Результати та їх обговорення}

За аналізу спостережень показано, що кількість комісійних судово-медичних експертиз щодо померлих осіб, у яких під час розтину було виявлено травми ПГК, у середньому становить $0,6 \%$ на рік від загальної їх кількості. Переважали травми ПГК у осіб чоловічої статі - 14 випадків (77,8 \% спостережень), більше половини потерпілих - 13 випадків (72,2 \% спостережень) - були працездатного віку - 20-50 років. Серед травм ПГК на першому місці стоять побутові травми. За механізмом виникнення ушкоджень ПГК у 8 випадках (44,4 \% спостережень) мала місце ударна дія тупих твердих предметів на шию (частіш за все удари пальцями рук, стислими в кулак, і тупими твердими предметами), у 4 випадках $(22,2 \%$ спостережень $)$ - стиснення шиї руками, у 2 випадках $(11,1 \%$ спостережень) - стиснення шиї тупими твердими предметами, у 2 випадках $(11,1 \%$ спостережень) - стиснення шиї руками та петлею та у 2 випадках (11,1 \% спостережень) - стиснення шиї петлею.

Характер виявлених при судово-медичній експертизі ушкоджень такий. У 16 потерпілих (88,9 \% спостережень) на шиї встановлено ушкодження м'яких тканин шкіри - синці, садна, які вказували на місце дії травматичної сили, крім того, у 2 постраждалих (11,1 \% спостережень) була наявна странгуляційна борозна; у 2 постраждалих (11,1 \% спостережень) будь-яких видимих ушкоджень на шиї не встановлено. Останнє ускладнювало судово-медичну діагностику.

Серед ушкоджень ПГК у більшості постраждалих - 13 (72,2 \% спостережень) - було встановлено переломи щитоподібного хряща гортані різного характеру та вираженості. Перелом щитоподібного хряща в місці з'єднання його пластин відмічено в 7 постраждалих (38,9 \% спостережень). Крім того, у цих постраждалих мали місце ушкодження інших структур ПГК та трахеї. Перелом першого хрящового півкільця трахеї був наявний в 1 постраждалого. Перелом одного з великих рогів під'язикової кістки встановлено у 2 постраждалих, у 1 з яких був наявний ще й перелом верхнього рога щитоподібного хряща. У 2 постраждалих мав місце повний поперечний перелом дуги перснеподібного хряща гортані по серединній лінії, у 1 з яких встановле- 
но ще й перелом верхнього рога щитоподібного хряща праворуч. Перелом тіла під'язикової кістки був наявний у 1 постраждалого, а ще в 1 встановлено фрагментарне роздроблення лівого черпалоподібного хряща, перелом перснеподібного хряща по лівій бічній його поверхні. У 6 постраждалих (33,3 \% спостережень) установлено тільки перелом верхнього рога щитоподібного хряща $з$ одного боку, у 3 з них мали місце ще й переломи великих рогів під’язикової кістки. У 5 постраждалих (27,8 \% спостережень) із ушкоджень ПГК спостерігались крововиливи в м'які тканини навколо гортані та на ії слизовій оболонці. При цьому у 3 постраждалих мали місце ще й переломи великих рогів під'язикової кістки.

Окрім ушкоджень структур ПГК у всіх постраждалих установлено тілесні ушкодження інших ділянок тіла різного характеру та тяжкості. Ушкодження м'яких тканин шкіри різних ділянок тіла у вигляді саден або синців мали місце в усіх постраждалих. Закриту черепномозкову травму та закриту травму грудної клітки встановлено у 8 постраждалих (44,4 \% спостережень), закриту тупу травму живота у 1 постраждалого (5,6 \% спостережень).

Морфологічні ознаки загрозливого для життя стану, а саме механічної асфіксії, за результатами судово-медичного розтину померлих осіб експертною комісією були встановлені у 12 постраждалих (66,7 \% спостережень). У 11 постраждалих (61,1 \% спостережень) за підсумками експертної комісії саме виникнення цього небезпечного для життя стану знаходилось у прямому причинному зв'язку із травмою органів шиї.

Причиною смерті у 10 постраждалих (55,6 \% спостережень) була механічна асфіксія внаслідок закритої травми органів шиї, що виникла від удавлення петлею, або дії на шию тупими твердими предметами. У 1 постраждалого (5,6 \% спостережень) смерть настала внаслідок закритої травми гортані з численними переломами щитоподібного хряща, що призвела до внутрішньої кровотечі, аспірації крові в дихальні шляхи та механічної асфіксії. У 1 постраждалого (5,6 \% спостережень) причиною смерті стала сукупна травма голови та шиї, ускладнена розвитком травматичного шоку. До смерті 1 постраждалого (5,6 \% спостережень) призвела закрита травма носа, що була ускладнена рясною кровотечею, аспіра- цією крові в дихальні шляхи та механічною асфіксією. У 3 постраждалих (16,7 \% спостережень) причиною смерті стала закрита тупа травма грудної клітки, ускладнена розвитком легенево-серцевої недостатності. У 1 постраждалого $(5,6 \%$ спостережень) причиною смерті стала тупа травма живота, що призвела до масивного внутрішньочеревного крововиливу. У 1 постраждалого (5,6 \% спостережень) причиною смерті стала закрита черепномозкова травма, що призвела до гострого порушення мозкового кровообігу. Таким чином, безпосередньо травма шиї з ушкодженням структур ПГК стала причиною смерті в 11 постраждалих (61,1 \% спостережень), у 1 постраждалого - у поєднанні із травмою голови. У решти постраждалих - 6 (35,3 \% спостережень) - причина смерті була пов'язана 3 ушкодженням інших органів і ділянок тіла.

Підставами призначення комісійних експертиз у випадках травм ПГК стали:

- сумніви слідчого, адвокатів, обвинувачуваних осіб у правильності встановленої причини смерті, ступеня тяжкості тілесних ушкоджень у ході первинних експертиз;

- протиріччя висновків експерта щодо встановленого механізму травм ПГК при проведенні первинної та подальших експертиз;

- поява додаткових судово-медичних даних;

- відсутність у висновках первинної та подальших експертиз відповідей на всі питання слідчого.

При судово-медичному експертному оцінюванні травм ПГК установлений такий ступінь тяжкості тілесних ушкоджень. Травми шиї 3 закритими ушкодженнями ПГК як тяжкі тілесні ушкодження за критерієм «небезпека для життя» «Правил...» оцінені у 12 постраждалих (66,7 \% спостережень), у 11 з яких розвинулась механічна асфіксія, а в 1 постраждалого - травматичний шок. При цьому, за висновками експертної комісії, причинний зв'язок між травмою шиї, асфіксією та смертю базувався переважно на виявленні судово-медичними експертами загальних асфіктичних, морфологічних іiі ознак та характері виявленої травми ПГК. Крім того, необхідно зазначити, що, на нашу думку, указаний причинний зв'язок не завжди знаходив відповідне переконливе експертне обгрунтування у висновках експертів.

У 6 постраждалих (33,3 \% спостережень) травми ПГК із переломами хрящів гортані 
кваліфіковано як такі, що мають ознаки ушкодження середнього ступеня тяжкості за критерієм «тривалого розладу здоров'я» (більш ніж 21 день) відповідно до п. 2.2.1 і 2.2.2 «Правил...». У цих випадках причинного зв'язку між травмою ПГК і виникненням небезпечних для життя явищ та смертю постраждалих експертами не встановлено. При цьому за характером самої травми у 3 випадках $(17,6 \%$ спостережень) мала місце закрита травма гортані 3 переломом пластин щитоподібного хряща у місці їхнього з'єднання. Крім того, у 1 з цих постраждалих мав місце ще повний поперечний перелом дуги перснеподібного хряща гортані по серединній лінії, а у 2 постраждалих переломи під'язикової кістки. У 3 випадках (17,6 \% спостережень) із ушкоджень ПГК мали місце тільки переломи верхнього рога щитоподібного хряща з одного боку. При цьому необхідно зазначити, що при формуванні експертних висновків щодо встановлення тяжкості травми ПГК у випадках відсутності небезпеки для життя, фахівці спирались лише на власний експертний досвід та досвід експертів-клініцистів, що входили у склад експертної комісії. Вони намагались спрогнозувати можливий кінцевий результат травми ПГК, яка мала місце в постраждалих, ураховуючи об'єм і тяжкість травми, тривалість відновлення цілості та функції гортані при такій травмі за умов спеціалізованого стаціонара. Однак у нас виникли сумніви щодо правильності встановленого ступеня тяжкості тілесних ушкоджень у постраждалих, у яких мав місце лише перелом верхнього рога щитоподібного хряща з одного боку, ураховуючи характер і тяжкість такого ушкодження.

Проаналізувавши науково-методичну літературу, яку можна застосувати для прогнозування кінцевого результату травм ПГК, що не $\epsilon$ небезпечними для життя в померлих осіб, ми встановили таке. У наявних монографіях та наукових роботах, виконаних фахівцями у галузі суміжних спеціальностей $[1,6-10]$, бракує даних щодо особливостей клінічного перебігу зазначених травм і їхніх ускладнень. А саме такі дані $\epsilon$ вкрай необхідними для завдань судово-медичної експертизи. Відомості щодо окремих видів можливих ушкоджень ПГК, їхніх клінічних симптомів, ускладнень, методів діагностики та лікування можуть бути корисні практикуючим лікарям-клініцис- там. Узагальнені клінічні ознаки травм і їхніх ускладнень наведено в обсязі, який $є$ необхідним для розпізнавання травми, установлення діагнозу та проведення адекватного лікування, а не для проведення судово-медичної експертизи $[8,9]$. Судово-медичному експерту перш за все необхідні чіткі діагностичні ознаки, що визначають строки появи тих чи інших симптомів травм ПГК, строки відновлення порушених у результаті травми функцій.

При судово-медичному оцінюванні наслідків і кінцевих результатів травм судово-медичні експерти повинні використовувати «Инструкцию о порядке организации и проведения врачебно-страховой экспертизы» (1986) [11]. У ст. 48 зазначеної інструкції вказано, що питання наслідків травм ПГК повинно бути вирішено не раніше ніж через 3 міс від моменту травми. При цьому, за якими критеріями повинно вирішуватись це питання, у інструкції не зазначено.

За нормативними судово-медичними документами деяких країн [12], необхідно застосовувати суто морфологічний підхід при судовомедичному оцінюванні травм ПГК та всі без винятку травми, що супроводжуються переломами хрящів гортані, незалежно від їхнього характеру відносити до тяжких тілесних ушкоджень як небезпечних для життя. Але останнє не знаходить відповідного наукового обгрунтування у наведених літературних джерелах.

\section{Висновки}

1. У відділі комісійних судово-медичних експертиз обласного бюро мають місце випадки, коли за ступенем тяжкості тілесних ушкоджень необхідно оцінити травми під'язиково-гортанного комплексу не тільки в живих осіб, але й у випадках смерті постраждалих. Судово-медичне оцінювання випадків тупої травми під'язиково-гортанного комплексу 3 формуванням переломів хрящів гортані та під'язикової кістки за відсутності небезпеки для життя часто становить певні труднощі для судово-медичної експертної комісії.

2. Науково-методична література не містить чітких морфологічних ознак, які є необхідними для якісного й об'єктивного прогнозування кінцевих результатів травм під'язиково-гортанного комплексу у випадках смерті постраждалих.

3. Підвищення ефективності судово-медичної діагностики травм під'язиково-гортанного комплексу може бути вирішено шляхом 
розробки фахового науково-методичного забезпечення, що буде містити чіткі діагностичні критерії експертного оцінювання для прогнозування наслідків і кінцевих результатів зазначених травм при визначенні ступеня тяжкості тілесних ушкоджень. Необхідним є запровадження в експертну практику чіткого алгоритму й уніфікації дій фахівців при проведенні експертизи в таких випадках.
Перспектива подальших досліджень полягає у продовженні наукової роботи з визначення всіх можливих клінічних проявів $\mathrm{i}$ кінцевих результатів травм під’язиково-гортанного комплексу, систематизації отриманих даних та вдосконаленні морфоклінічного підходу, що застосовується в Україні при судовомедичному оцінюванні тяжкості проаналізованої травми.

\section{Список літератури}

1. Говорун М. И. Повреждения ЛОР-органов и шеи в мирное и военное время : руководство для врачей / М. И. Говорун, А. А. Горохов. - СПб. : СпецЛит, 2010. - 126 с.

2. Смирнов Р. Ю. Судебная медицина (судебно-медицинская оценка вреда здоровью) : учебнометодическое пособие / Р. Ю. Смирнов. - Ярославль : ЯрГУ, 2018. - 52 с.

3. Клевно B. А. Определение степени тяжести вреда здоровью. Применение правил и медицинских критериев. Ответы на вопросы / В. А. Клевно, И. Н. Богомолова. - М. : ГЭОТАР-Медиа, 2010. - 136 с.

4. Хохлов В. В. Судебная медицина : руководство / В. В. Хохлов. - [3-е изд-е, перераб. и доп.]. Смоленск, 2010. - 992 с.

5. Правила судово-медичного визначення ступеня тяжкості тілесних ушкоджень // Про розвиток та вдосконалення судово-медичної служби України : Наказ МОЗ України від 17.01.95 № 6. - К., 1995. - 220 с.

6. Юнина А. И. Травмы органов шеи и их осложнения / А. И. Юнина. - М. : Медицина, 1972. - 208 с.

7. Moonsamy P. Management of laryngotracheal trauma / P. Moonsamy, U. M. Sachdeva, C.R. Morse // Ann. Cardiothorac. Surg. - 2018. - № 7 (2). - P. 210-216.

8. Laryngeal fractures: clinical findings and considerations on suboptimal outcome / M. Juutilainen, J. Vintturi, S. Robinson [et al.] // Acta Otolaryngol. - 2008. - № 128 (2). - P. 213-218.

9. Omakobia E. Approach to the patient with external laryngeal trauma: The Schaefer Classification / E. Omakobia, A. Micallef // Otolaryngol. (Sunnyvale). - 2016. - Vol. 6 (2). - P. 230.

10. Зенгер В. Г. Повреждения гортани и трахеи / В. Г. Зенгер, А. Н. Наседкин. - М. : Медицина, 1991. -240 с.

11. Инструкция о порядке организации и проведения врачебно-страховой экспертизы. - М. : Финансы и статистика, 1986. - 110 с.

12. Клевно B. A. Нормативные правовые документы, регулирующие порядок определения степени тяжести вреда, причиненного здоровью человека / В. А. Клевно. - М., 2009. - 64 с.

\section{References}

1. Hovorun M.I., Horokhov A.A. (2010). Povrezhdeniia LOR-orhanov $i$ shei v mirnoie $i$ voiennoie vremia: rukovodstvo dlia vrachei [Damage of ENT organs and neck in peace and war time: a guide for doctors]. St. Petersburg: SpetsLit, 126 p. [in Russian].

2. Smirnov R.Yu. (2018). Sudebnaia meditsina (sudebno-meditsinskaia otsenka vreda zdoroviu): uchebno-metodicheskoie posobiie [Forensic medicine (forensic medical assessment of harm to health): a teaching guide manual]. Yaroslavl: YarGU, 52 p. [in Russian].

3. Klevno V.A., Bohomolova I.N. (2010). Opredeleniie stepeni tiazhesti vreda zdoroviu. Primeneniie pravil $i$ meditsinskikh kriteriiev. Otvety na voprosy [Determining the severity of the harm to health. Application of rules and medical criteria. Answers to questions]. Moscow: HEOTAR-Media, 136 p. [in Russian].

4. Khohlov V.V. (2010). Sudebnaia meditsina: rukovodstvo [Forensic medicine: a guide]. (3d ed.). Smolensk, 992 p. [in Russian].

5. Pravyla sudovo-medychnoho vyznachennia stupenia tiazhkosti tilesnykh ushkodzhen [Rules of forensic medical assessment of severity of bodily injuries]. (1995). Nakaz MOZ Ukrainy № 6 vid 17.01.95. Pro rozvytok ta vdoskonalennia sudovo-medychnoi sluzhby Ukrainy [Order of the Ministry of Health of Ukraine dated 17.01.95 № 6. About the development and improvement of the forensic service of Ukraine]. Kyiv, 220 p. [in Ukrainian]. 
6. Yunina A.I. (1972). Travmy orhanov shei i ikh oslozhneniia [Injuries of the neck organs and their complications]. Moscow: Meditsina, 208 p. [in Russian].

7. Moonsamy P., Sachdeva U.M., Morse C.R. (2018). Management of laryngotracheal trauma. Ann. Cardiothorac. Surg., № 7 (2), pp. 210-216.

8. Juutilainen M., Vintturi J., Robinson S., Back L., Lehtonen H., Makitie A.A. (2008). Laryngeal fractures: clinical findings and considerations on suboptimal outcome. Acta Otolaryngol., № 128 (2), pp. 213-218.

9. Omakobia E., Micallef A. (2016). Approach to the patient with external laryngeal trauma: the Schaefer classification. Otolaryngol. (Sunnyvale), vol. 6 (2), pp. 230.

10. Zenger V.H., Nasedkin A.N. (1991). Povrezhdeniia hortani i trakhei [Damage of the larynx and trachea]. Moscow: Meditsina, 240 p. [in Russian].

11. Instruktsiia o poriadke orhanizatsii i provedeniia vrachebno-strakhovoi ekspertizy [Instructions of the organization and carrying out of medical insurance expertise]. (1986). Moscow: Finansy i statistika, 110 p. [in Russian].

12. Klevno V.A. (2009). Normativnyie pravovyie dokumenty, rehuliruiushchiie poriadok opredeleniia stepeni tiazhesti vreda, prichinennoho zdoroviu cheloveka [Regulatory legal documents regulating the procedure for determining the severity of harm caused to human health]. Moscow, $64 \mathrm{p}$. [in Russian].

\section{Н.В. Губин \\ СУДЕБНО-МЕДИЦИНСКАЯ ОЦЕНКА ТЯЖЕСТИ ПОСТТРАВМАТИЧЕСКИХ ИЗМЕНЕНИЙ ПОДЪЯЗЧЧО-ГОРТАННОГО КОМПЛЕКСА В СМЕРТЕЛЬНЫХ СЛУЧАЯХ}

Установлены особенности проведения судебно-медицинских экспертиз при определении степени тяжести телесных повреждений при смерти пострадавших лиц с травмами подъязычно-гортанного комплекса. Проанализировано методическое обеспечение для проведения адекватной судебно-медицинской оценки таких травм. При анализе четких диагностических критериев, которые позволяют объективно определять степень тяжести телесных повреждений при смерти лиц с травмами подъязычно-гортанного комплекса, не выявлены. Определены пути дальнейшего усовершенствования судебно-медицинской оценки указанных травм в случаях смерти пострадавших.

Ключевые слова: судебно-медицинская экспертиза, травма гортани, диагностические критерии, степень тяжести телесных повреждений.

\section{N.V. Gubin}

\section{FORENSIC-MEDICAL ESTIMATION OF THE SEVERITY OF POSTTRAUMATIC CHANGES OF THE HYOID-LARYNGEAL COMPLEX IN DEATH CASES}

Features of carrying out of forensic medical examinations in determining the severity of bodily injuries after the death of injured persons with traumas of the hyoid-laryngeal complex were established. The methodological support for an adequate forensic-medical assessment of such injuries was analyzed. The analysis showed the absence of strong diagnostic criteria that can objectively determine the severity of bodily injuries during the death of persons with injuries of the hyoid-laryngeal complex. Ways of further improvement of the forensic-medical assessment of such injuries in cases of death of the victims were determined.

Keywords: forensic-medical examination, larynx injury, diagnostic criteria, severity level of bodily injuries.

Надійшла 23.04.19

\section{Відомості про автора}

Губін Микола Володимирович - кандидат медичних наук, доцент кафедри судової медицини, медичного правознавства ім. засл. проф. М.С. Бокаріуса Харківського національного медичного університету.

Адреса: 61052, м. Харків, вул. Дмитрівська, 14/16, кафедра судової медицини, медичного правознавства ім. засл. проф. М.С. Бокаріуса ХНМУ.

Тел.: +38(050)301-24-00

E-mail: n-gubin@ukr.net.

ORCID: https://orcid.org/0000-0002-2383-3211. 